\title{
Alcohol Consumption Habits of Tuberculosis Patients
}

\author{
Andrea MÜLLER-FABIAN ${ }^{1}$ \\ ${ }^{1}$ Faculty of Sociology and Social Work, Babes-Bolyai University, Romania, str. Kogalniceanu nr.1, Cluj- \\ Napoca, Romania . \\ ${ }^{*}$ Corresponding author, e-mail: andreea_fabian_ubb@yahoo.com
}

Bulletin UASVM Horticulture 72(1) / 2015

Print ISSN 1843-5254, Electronic ISSN 1843-5394

Doi:10.15835/buasvmcn-hort:10662

\begin{abstract}
The representatives of the Ministry of Health have stated that the causes bringing about the ranking of Romania on the "negative list" in Europe regarding the occurrence of tuberculosis are the consequences of the poor social, economic and educational level of a segment of population. Besides this fact, the other causes for its high occurrence are smoking and chronic alcoholism. The general purpose of the researchis the assessment of psycho-social and economic level of tuberculosis patients in order to develop an intervention program, whereas its specific purpose is the assessment of alcohol consumption habits in the population subjected to scrutiny. In consequence, a population of 205 tuberculosis patients from Cluj-Napoca was put under investigation, which was conducted with the following research instruments: questionnaires, individualized semi-structured interviews and document analysis. The results have shown that social, cultural and economic factors are playing a crucial role in the development of chronic tuberculosis and that the patients, who are already being hospitalized for a long time because of this sickness, register frequent set-backs for not changing their lifestyle (alcohol and drug consumption habits). It follows that the role of prevention and intervention in the framework of social work is very important.

Keywords: alcohol consumption, economic level, educational level, social level, tuberculosis.
\end{abstract}

\section{INTRODUCTION}

WHO estimates that tuberculosis (TB), a contagious airborne disease caused by Mycobacterium tuberculosis, affects one third of the world's population. The report of the European Centre for Disease Prevention and Control (ECDC) and WHO Regional Office for Europe (2012) ranked Romania as one of the 18 High-Priority countries in Europe with regard to the occurrence of tuberculosis cases.

\section{AIMS AND OBJECTIVES}

The research aim is the assessment of psychosocial-familial and economic level of tuberculosis patients in order to develop an intervention program. Its objective is the assessment of alcohol consumption habits of the research population.

\section{MATERIALS AND METHODS}

The instruments of research were questionnaires (Screening Socio-cultural aspects of TB patients; STAI FX1 - anxiety scale, Spielberger,
1989) individualized semi-structured interviews and document analysis. The population subjected to research, was chosen randomly out of the patients being interned in the Leon Daniello TB Clinical Hospital from Cluj-Napoca during the March 2013-March 2014 period. In this researched period there were hospitalized 593 TBC patients which correspond to the research population. The sampling method was the following: out of the patients there were chosen randomly, in each months 20 patients. In this way, during the researched period we succeeded to collect valid answers from 205 tuberculosis patients.

\section{RESULTS AND DISCUSSION}

Most of the patients are male (71.2\%) aged between 36-60 years old (45.3\%). Romanian nationalities were declared by $71 \%$ of them, $15 \%$ are Hungarians and the rest $(14 \%)$ are Roma. The majority of the research population comes originally from an urban environment (74\%). This confirms the results obtained by Fabian et al. (1997) regarding 
the urban provenance of most tuberculosis patients. Part of the research patients graduated vocational school (35\%) or primary school (35\%); $4 \%$ of them have less than 4 classes, $13 \%$ have twelve classes, $7 \%$ are college graduates and $6 \%$ possess a university degree. A research conducted in Hungary in 2000 underlined the low degree of school integration for tuberculosis patients: $12,5 \%$ of them did not graduate from primary school, whereas $35 \%$ had only been through 8 years of schooling (www.agria. hu, 2000). Regarding their living conditions $19 \%$ of the patients has no stable home. From another point of view $49 \%$ of the interviewed patients are retired, $23 \%$ are jobless, while only $19 \%$ of them enjoy stable work, and $9 \%$ only temporary work. The temporary jobs are in ménage. From the research population, $31 \%$ declared that they have very low income (lower than the minimum/population), and $7 \%$ of them had more than a good income (they were successful contractors). Regarding the harmful working environment, $80 \%$ of the patients declared that they were confronted with this situation. The younger patients and those who graduated 12 classes, college or are in apossession of a university degree declared more occupational risk $(\mathrm{p}=0.006)$, while patients with low educational level stated (ca sa mai schimbam) that they face only one occupational risk $(\mathrm{p}=0,008)$. The research that took place in Hungary (www.agraria.hu, 2000) suggested that 35\% from patients consume alcohol, and 98\% are smokers. For the case in question (nu mi-e clar aici despre ce e vorba) however the situation is more severe concerning the alcohol intake because $78.9 \%$ of the male patients consume alcohol, while $81.7 \%$ of them prefer hootch. Most of them (57.3\%) are 41-60 years old. Only $7 \%$ of the women patients declared that they consume alcohol. Fabian et al. (1997) showed that $50 \%$ of the patients were alcohol consumers, and $30 \%$ were severe alcoholists. Most patients are smokers (82.5\%), $72 \%$ of them smoking more than over 15 years. There is significance $(p=0.013)$ regarding alcohol consumption with regard to smoker and non-smoker patients. From the group of the smokers $76.7 \%$ consume alcohol, while only a few non-smokers consume alcohol. It was interesting to find that those patients who are smokers have a lower income than those who are non-smokers $(p=0,003)$. There is significance regarding the parental families alcohol consumption of the male and female patients ( $p=0.017)$. In most of the cases, female patients declared the existence of alcohol consumers in their parental family. There were one or more persons diagnosed with TB in $25,7 \%$ of the patients' parental family. There is significance $(p=0,017)$ regarding the number of persons with TB from the families from urban and rural area. Patients from rural area declared that they have two or more persons in their family diagnosed with TB, while patients from urban area declared that they have only one person in their family diagnosed with TB.

In order to assess the anxiety level of the patients, we used the STAI F.X-1 questionnaire. In case of $25,1 \%$ we found low anxiety, for $48,3 \%$ moderate level of anxiety and for $26,6 \%$ high level of anxiety. There is a significant connection between the scale measuring anxiety and income $(p=0,017)$ attention to decimal separator, smoking $(p=0,019)$, alcohol consumption $(p=0,015)$, number of sick persons in the family $(p=0,002)$, multiple hospitalization $(p=0,013)$ and anxiety factor $(p<0,001)$. The patients with high values on the anxiety scale: have very low income, while those with better material conditions have lower anxiety values; are mainly non-smokers, while smokers have lower values; have higher rates of alcohol consumption; have more TB patients in their family of origin; have been hospitalized several times because of their illness; their anxiety factor has more significantly medium or high values.

\section{CONCLUSION}

The social, cultural, and economic factors play a crucial role in the evolution of chronic TB. In order to achieve an efficient intervention, it must envisage and produce effects on several levels at the same time: personal, family, community.

\section{REFERENCES}

1. Spielberger CD (1989). State-Trait Anxiety Inventory: Bibliography (2nd ed.). Palo Alto, CA: Consulting Psychologists Press.

2. European Centre for Disease Prevention and Control/WHO Regional Office for Europe. Tuberculosis surveillance and monitoring in Europe 2012. Stockholm: European Centre for Disease Prevention and Control, 2012.

3. Fabian A, Zamora C, Fabian A (1997). Klinikánkon kezelt krónikus TBC-s betegeink szociális háttere. A magyar belgyógyász társaság északkelet-magyarország szakcsoportjának tudományos ülése. Gyöngyös, Appendix, 27.

4. WHO (2012). Global tuberculosis report 2012, pp.3.

5. www.agria.hu/hmhirlap/archiv/2000/0110/tebece.htm 